\title{
ANALISIS KINERJA KEUANGAN TERHADAP HARGA PASAR SAHAM PADA PERUSAHAN PEMBIAYAAN TERBUKA
}

\author{
Pariang Siagian \\ Accounting and Finance Department, Faculty of Economic and Communication, BINUS University \\ Jln. K. H. Syahdan No. 9, Palmerah, Jakarta Barat 11480 \\ parsiagian@yahoo.com
}

\begin{abstract}
The main purpose of this article is to inform the result of research and analysis of financial performace effects to the stock market price done to go public financing companies in 2008-2012. Financial performance was assessed based on annual financial statements published on the website of each company and stock market price from the Stock Exchange's website by the end of research period. Analysis of the financial performance limited on four financial ratios as representation of its financial ratios, such Current Ratio, Asset Turn Over, Return On Asset, and Debt Ratio. From the research and analysis obtained, there are significant effects from various independent variables to dependend variable, with $t$ value: Current Ratio 0,738, Asset Turn Over 0,121, Return On Asset 0,703, and Debt Ratio 0,374; likewise simultaneously test with F value 0,41. All values showed more than 0,05; that it can be concluded there are significant effects between each independent variable and simultaneously to the dependent variable.
\end{abstract}

Keywords: financial performance, current ratio, asset turn over, return on asset, debt ratio, stock market

\begin{abstract}
ABSTRAK
Tujuan utama tulisan ini adalah untuk menginformasikan hasil penelitian dan pembahasan yang dilakukan atas pengujian pengaruh kinerja keuangan terhadap harga pasar saham perusahaan pembiayaan terbuka periode 2008-2012. Kinerja keuangan dinilai berdasarkan data yang didapatkan dari laporan keuangan tahunan yang diterbitkan di website masing-masing perusahaan dan harga pasar saham yang didapatkan dari website BEI per akhir tahun periode penelitian. Pembahasan kinerja keuangan dibatasi dengan menggunakan empat rasio keuangan yang dianggap sebagai representasi masing-masing kelompok rasio keuangan yang ada: rasio lancar, rasio perputaran aset, tingkat pengembalian aset, dan rasio utang. Berdasarkan hasil penelitian dan analisis yang dilakukan, hasil menunjukkan nilai-t dengan Current Ratio 0,738, Asset Turn Over 0,121, Return On Asset 0,703, dan Debt Ratio 0,374. Demikian juga pengujian secara bersama-sama dengan nilai $F$ sebesar 0,41. Dari semua hasil perhitungan, dapat disimpulkan bahwa ada pengaruh signifikan antara masingmasing variabel independen maupun secara bersama-sama terhadap variabel dependen.
\end{abstract}

Kata kunci: kinerja keuangan, rasio lancar, perputaran aset, tingkat pengembalian aset, rasio utang, pasar saham 


\section{PENDAHULUAN}

Perusahaan pembiayaan (financing company) merupakan suatu system pembiayaan yang dapat membantu perusahaan kecil, menengah, dan besar untuk mengatasi pendanaan dalam memperoleh sejumlah dana untuk kegiatan operasional dan pengadaan alat-alat atau barang modal yang dibutuhkan. Oleh karena itu, perusahaan yang memiliki dana kurang dapat memanfaatkan jasa beberapa jenis pembiayaan untuk pengadaan barang modal yang dibutuhkan. Namun dalam kenyataannya, pemanfaatan sistem ini bukan hanya digunakan perusahaan dengan tujuan untuk menjalankan aktivitas bisnis dalam menghasilkan pendapatan dan keuntungan, melainkan banyak juga digunakan masyarakat umum kepada hal yang tidak ada kaitan dengan pelaksanaan suatu aktivitas bisnis yang bersifat produktif. Dalam hal ini perusahaan pembiayaan banyak melayani masyarakat dalam memenuhi permintaan untuk mendapatkan sejumlah dana dan berbagai barang yang bersifat konsumtif, seperti pengadaan kendaraan mobil dan sepeda motor, produk elektronik, maupun perabotan rumah tangga lainnya. Memang diakui, ada banyak manfaat menggunakan jasa perusahaan pembiayaan, utamanya perusahaan dan konsumen dapat melakukan alokasi biaya yang dimiliki kepada objek biaya lainnya demikian juga upaya penghematan tunai dibandingkan jika membeli suatu barang secara tunai.

Dalam berbagai kegiatan pembiayaan, diakui bahwa masih banyak konsumen kurang memahami secara baik akan isi perjanjian bisnis yang dijalankan termasuk berbagai risiko yang akan ditanggung kemudian hari. Misalnya, dalam bisnis leasing, banyak nasabah tidak mengetahui risiko yang akan ditanggung sehubungan keterlambatan pembayaran sesuai dengan tanggal jatuh tempo. Kemudian, tidak sedikit juga konsumen mendapatkan perlakuan yang kurang wajar dari pihak perusahaan pembiayaan seperti dalam melakukan penagihan melalui penggunaan jasa debt collector. Risiko lain yang sangat membebankan konsumen adalah besarnya tingkat bunga yang haru dibayar. Beban tingkat bunga ini relatif tinggi karena di luar kewajaran jika dibandingkan dengan tingkat bunga pinjaman bank. Dalam keadaan ini, masyarakat sebagai pengguna jasa, kurang atau tidak memahami cara penetapan tingkat bunga yang ditawarkan dan dibebankan pihak perusahaan. Mereka hanya disodorkan satu lembar tabel cicilan yang akan dibayar setiap periode tertentu, tanpa mempertanyakan dan memahami dasar penentuan jumlah cicilan tersebut.

Pesatnya perkembangan jenis usaha ini diakui cukup mengembirakan. Hal ini dirasa dapat menstimulasi kegiatan perekonomian baik yang bersifat lokal maupun nasional. Beberapa calon investor tertarik untuk berinvestasi dan bahkan menjadi pelaku usaha di bidang bisnis ini karena masyarakat sebagai calon konsumen banyak memanfaatkan jasa usaha pembiayaan ini. Berbagai faktor yang diduga memengaruhi pesatnya perkembangan usaha pembiayaan seperti leasing di Indonesia, di antaranya adalah syarat yang relatif ringan, intensitas promosi yang dilakukan, uang muka (Down Payment) yang ringan, peraturan pemerintah atau undang-undang, tingginya tingkat konsumtif masyarakat, kemampuan finansial nasabah yang tidak cukup untuk membeli tunai, akses yang mudah dan tidak memerlukan agunan (Leenden, 2003).

Pertumbuhan industri pembiayaan selama kurun waktu 5 tahun terakhir ini di Indonesia mengalami perkembangan yang cukup pesat dan mengembirakan. Setelah industri asuransi, perusahaan pembiayaan (leasing) menduduki peringkat kedua (Laptah 2010 Perusahaan Pembiayaan). Di Indonesia ada beberapa jenis perusahaan pembiayaan yang menjalankan operasionalnya, seperti pembiayaan konsumen (costumers goods), kartu kredit (credit cards), anjak piutang (factoring), dan yang paling banyak adalah sewaguna usaha (leasing). Semua aktivitas perusahaan ini sudah barang tentu berdampak positif pada sektor riil yang dapat meningkatkan pembangunan ekonomi secara nasional. Setelah krisis keuangan global tahun 2008, perkembangan perusahaan pembiayaan kembali mengalami pertumbuhan pada 2009 meskipun belum mampu mencapai keberhasilan seperti 2 tahun sebelumnya, dengan PDB nominal mengalami peningkatan sebesar 4,5\% dari tahun sebelumnya. Hal 
ini disebabkan peran sektor konsumsi yang besar walaupun sektor ekspor mengalami penurunan. Pada 2009 nilai aset perusahaan pembiayaan mencapai Rp174,4 triliun atau naik 3,1\% dari PDB dengan pertumbuhan 16,6\% (Laptah Bapepam - LK, 2009).

Tahun 2010 dapat dikatakan sebagai tahun pemulihan ekonomi dunia karena pertumbuhan ekonomi pada waktu itu sebesar $5 \%$. Hal ini dipicu pertumbuhan ekonomi negara-negara berkembang, khususnya di Asia sebesar 9,3\% dan Indonesia dengan pertumbuhan 6,1\%. Akibat pertumbuhan perekonomian yang baik ini memberi dampak positif terhadap perkembangan usaha pembiayaan. Berbagai indikator utama yang dapat menunjukkan ini adalah perolehan laba yang cukup menggembirakan, yakni naik rata-rata 14\% dan sumbangsih terhadap PDB, naik 0,33\% dari 2006 menjadi 3,59\% pada 2010. (Laptah Bapemam - LK, 2010)

Secara umum dinamika laju pertumbuhan ekonomi global pada 2011 mengalami penurunan pertumbuhan sebesar 1,41\% jika dibandingkan dengan 2010. Keadaan ini disebabkan krisis utang yang dimiliki negara-negara Eropa sehingga berakibat pemulihan perekonomian global mengalami hambatan. Faktor lain disebabkan tingginya tingkat pengangguran di negara-negara maju termasuk Amerika Serikat. Namun sebaliknya, pertumbuhan di negara-negara Asia masih menunjukkan konsistensi selama 2011. Karena secara keseluruhan dengan tingkat permintaan dari internal Asia mampu menyerap tingkat output yang dihasilkan oleh sektor produksi yang ada. Sebagai negara Asia, Indonesia masih menunjukkan tingkat pertumbuhan yang mengembirakan sebesar 6,5\%. Keadaan ini mendorong industri pembiayaan mengalami pertumbuhan sebesar 26,53\%. Tingkat pertumbuhan sedemikian ini juga dibarengi dengan sifat prudensial dari berbagai perusahaan pembiayaan dalam mewujudkan pelayanan kepada para nasabah. Indikatornya adalah adanya penurunan rasio risiko NPF (Non-Performance Financing) dari 2,7\% pada 2008 menjadi 1,2\% pada 2011. Kemudian peningkatan perolehan laba bersih sebesar 2,41\%.

Peningkatan kinerja perusahaan pembiayaan di Indonesia juga ditopang dengan makin meningkatnya pengawasan yang dilakukan oleh otoritas pengawas dan pembina, yakni Bapepam LK. Memang setelah mengalami kontraksi pada 2009, perusahaan pembiayaan makin berkembang pesat dan pertumbuhannya berada pada peringkat kedua setelah perusahaan asuransi sebagai perusahaan pembiayaan nonbank, sehingga berakibat peningkatan harga-harga pasar saham perusahaan pembiayaan go public, walaupun diakui ada sedikit dari perusahaan tersebut mengalami penurunan kinerja keuangan. Kebanyakan perusahaan pembiayaan yang beroperasi di Indonesia masih berlokasi di kota-kota besar seperti Jakarta, Surabaya, Medan, dan sebagainya. Dengan pertumbuhan ekonomi yang mengembirakan yang pada gilirannya mengakibatkan pertumbuhan kinerja perusahaan pembiayaan yang cukup signifikan, membuat para investor berkeinginan dan mau terlibat berinvestasi di bidang industri pembiayaan ini karena dianggap kinerja keuangannya baik dan diduga berkibat harga pasar saham terus mengalami peningkatan. Setiap investor pasti mengharapkan sejumlah return karena tujuan orang melakukan investasi adalah untuk menghasilkan uang (Tandelilin, 2011).

Dalam penelitian sebelumnya yang dilakukan oleh Anwar (2009), diketahui bahwa kinerja keuangan perusahaan pembiayaan yang diwakili antara lain: GPM, NPM, dan OPM berpengaruh secara signifikan terhadap harga saham (Anwar, 2009). Oleh karena itu, penulis merasa tertarik untuk melakukan penelitian dan kajian atas perusahaan pembiayaan ini, sehingga menentukan topik penelitian “Analisis Pengaruh Kinerja Keuangan Terhadap Harga Pasar Saham Pada Perusahaan Pembiayaan Terbuka”.

Identifikasi permasalahan dalam penelitian ini adalah apakah ada atau tidak adanya pengaruh kinerja keuangan terhadap harga pasar saham. Beberapa indikator kinerja keuangan yang digunakan, yaitu: rasio likuiditas yang diwakili oleh rasio lancar, rasio aktivitas yang dinyatakan dengan rasio perputaran aset, rasio keuntungan dengan rasio pengembalian aset, dan terakhir rasio utang yang dinyatakan dengan rasio utang terhadap aset. Dengan demikian tujuan penelitian ini adalah untuk membahas dan mengetahui ada tidaknya pengaruh kinerja keuangan terhadap harga pasar beberapa 
perusahaan pembiayaan terbuka yang terdaftar di Bursa Efek Indonesia (BEI), dan diharapkan dapat berguna bagi penulis sebagai bahan masukan untuk lebih meningkatkan pelaksanaan penelitian, bagi pembaca dapat digunakan sebagai referensi dalam meningkatkan wawasan tentang pengaruh kinerja keuangan terhadap harga saham perusahaan pembiayaan, bagi manajemen perusahaan pembiayaan diharapkan dapat meningkatkan kualitas perencanaan atau kebijakan pada masa mendatang, bagi calon investor dan investor dapat menambah pengetahuan tentang kebijakan pengambilan keputusan dalam berinvestasi.

\section{METODE}

Guna mendapatkan data yang diperlukan, penelitian menggunakan teknik pengumpulan data studi kepustakaan (library research), dengan terlebih dahulu mempelajari berbagai buku dan referensi artikel di samping melakukan riset terhadap berbagai textbook yang berkaitan. Pengumpulan data yang diolah dilakukan dengan mencari ke masing-masing website perusahaan pembiayaan terbuka. Data sekunder yang diperlukan didapatkan lewat berbagai website untuk memperoleh data pendukung yang akan dikelola. Populasi dalam penelitian ini adalah seluruh perusahaan pembiayaan terbuka yang berada di website Bursa Efek Indonesia dan Bapepam - LK, yakni sejumlah 14 perusahaan. Sampel yang digunakan adalah 6 perusahaan pembiayaan yang sudah go public, dengan kriteria sudah menjual saham secara umum minimum 5 tahun, yakni dari 2008 hingga 2012, memiliki dan mempublikasikan laporan keuangan Neraca dan Rugi Laba, serta histori harga pasar saham selama periode penelitian yang sudah dipublikasikan di website secara terbuka. Sementara teknik penentuan sampel adalah purposive sampling (Sugiyono, 2005), yakni sampel diambil secara sengaja dari populasi yang dianggap representatif atau sudah memenuhi kriteria sesuai dengan kebutuhan data dalam penelitian.

Adapun 6 sampel perusahaan sebagai objek penelitian adalah PT Clipan Finance, Tbk (CFIN), PT WOM Finance, Tbk. (WOMF), PT Adira Multi Finance, Tbk. (ADMF), PT BFI Finance, Tbk. (BIFN), PT Verena Oto Finance, Tbk. (VRNA), dan PT Dana Supra Erapacific, Tbk. (DEFI). Metode penelitian bersifat kuantitatif dengan teknis analisis data menggunakan program SPSS (Statistical Product and Service Solution). Analisis dilakukan secara bertahap, yakni uji normalitas data untuk menguji apakah data yang diolah dalam keadaan normal atau tidak. Jika hasil pengujian data bersifat normal, data tersebut dianggap dapat mewakili populasi (Priyatno, 2011). Jika data pada setiap variabel tidak normal, pengujian hipotesis tidak bisa menggunakan statistik parametris. Kemudian, pengujian multikolinearitas dilakukan untuk mengetahui apakah dalam model diketemukan adanya korelasi antarvariabel bebas. Pada model regresi yang baik seharusnya tidak terjadi korelasi diantara berbagai variabel independen. Pengujian terakhir dilakukan adalah pengujian hipotesis guna melihat ada tidaknya pengaruh antara variabel-variabel independen dengan variabel dependen, baik secara parsial maupun bersama-sama. Uji signifikansi hubungan antara variabel secara individual maupun berganda menggunakan formula signifikansi korelasi Product Moment (Pratisto, 2009).

Selanjutnya, variabel penelitian yang digunakan adalah beberapa variabel independen yang menggambaran kinerja keuangan perusahaan pembiayaan, yakni: kelompok Liquidity Ratio berupa Current Ratio (X1), Activity Ratio berupa Assets Turn Over (X2), Profitability Ratio berupa Return On Asset (X3), dan Leverage Ratio berupa Total Debt to Total Asset (X4). Sementara variabel dependen adalah Market Price Shares (Y). Masing-masing rasio dihitung berdasarkan data yang diperoleh dari laporan keuangan neraca dan pendapatan perusahaan, kemudian dihitung rata-rata setiap rasio dari seluruh perusahaan. Sementara harga pasar saham yang diperoleh adalah dengan menghitung rata-rata harga saham bulanan seluruh perusahaan selama periode penelitian. Lokasi penelitian dilakukan pada website setiap perusahaan pembiayaan yang diteliti dengan obyek penelitian berupa laporan keuangan tahunan Rugi Laba dan Neraca serta website BEI dan www.yahoo.com/finance guna mendapatkan 
histori Harga Pasar Saham bulanan dan kemudian dihitung rata-rata harga pasar saham bulanan pada setiap tahun 2008, 2009, 2010, 2011, dan 2012. Pengembangan hipotesis adalah sebagai berikut.
Ho1 : Rasio Lancar (X1) tidak berpengaruh terhadap Harga Pasar Saham (Y).
Ha1 : Rasio Lancar (X1) berpengaruh terhadap Harga Pasar Saham (Y).
Ho2 : Rasio Perputaran Aset (X2) tidak berpengaruh terhadap Harga Pasar Saham (Y).
Ha2 : Rasio Perputaran Aset (X2) berpengaruh terhadap Harga Pasar Saham (Y).
Ho3 : Rasio Pengembalian Aset (X3) tidak berpengaruh terhadap Harga Pasar Saham (Y).
Ha3 : Rasio Pengembalian Aset (X3) berpengaruh terhadap Harga Pasar Saham (Y).
Ho4 : Rasio Utang terhadap Aset (X4) tidak berpengaruh terhadap Harga Pasar Saham (Y).
Ha4 : Rasio Utang terhadap Aset (X4) berpengaruh terhadap Harga Pasar Saham (Y).
Ho5 : X1, X2, X3, dan X4 secara simultan tidak berpengaruh terhadap Harga Pasar Saham $(\mathrm{Y})$.
Ha5 : X1, X2, X3, dan X4 secara simultan berpengaruh terhadap Harga Pasar Saham (Y).

\section{HASIL DAN PEMBAHASAN}

Berikut adalah uraian hasil penelitian dan olah data sekunder yang dilakukan terhadap objek penelitian guna mengetahui apakah ada atau tidak adanya pengaruh kinerja keuangan yang diwakili dengan CR, ATO, ROA, dan DR terhadap Harga Pasar Saham pada 6 perusahaan pembiayaan terbuka selama periode $2008-2012$.

\section{Uji Asumsi Klasik}

Uji normalitas; seperti diketahui uji normalitas bertujuan untuk menguji apakah dalam model regresi data memiliki distribusi normal. Model regeresi dapat dikatakan baik jika memiliki distribusi normal atau mendekati normal. Berdasarkan hasil pengujian yang dilakukan, data memiliki distribusi normal seperti yang ditunjukkan pada tabel berikut.

Tabel 1 Hasil Tes Normalitas

\begin{tabular}{lrrrrrr}
\hline & \multicolumn{3}{c}{ Kolmogorov-Smirnov $^{\mathrm{a}}$} & \multicolumn{3}{c}{ Shapiro-Wilk } \\
\cline { 2 - 7 } & Statistic & df & \multicolumn{1}{c}{ Sig. } & Statistic & df & \multicolumn{1}{c}{ Sig. } \\
\hline Current Ratio &, 390 & 5 &, 012 &, 727 & 5 &, 018 \\
Asset Turn Over &, 231 & 5 &, $200^{*}$ &, 881 & 5 &, 314 \\
Return On Asset &, 367 & 5 &, 026 &, 684 & 5 &, 006 \\
Debt to Asset Ratio &, 231 & 5 &, $200^{*}$ &, 881 & 5 &, 314 \\
Harga Pasar Saham &, 262 & 5 &, $200^{*}$ &, 895 & 5 &, 383 \\
\hline
\end{tabular}

(Sumber: diolah sendiri)

Hasil uji normalitas data yang dilakukan dengan uji Kolmogorov-Smirnov (K-S) yang semuanya menunjukkan nilai signifikansi di atas 0,05, maka dapat disimpulkan bahwa data residual memiliki distribusi normal.

Selain itu, uji normalitas juga didukung oleh hasil analisis grafik, yakni dengan menggunakan grafik normal profitability - plot seperti terlihat pada Gambar 1. 


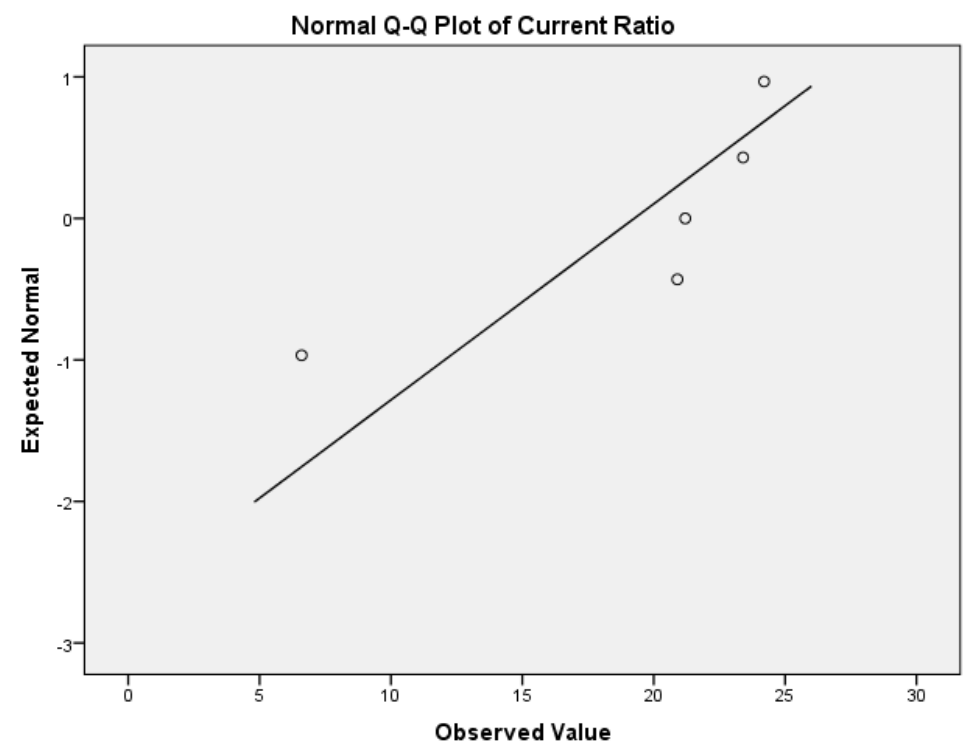

Gambar 1 Uji Grafik Normal P-Plot

Pada Gambar terlihat bahwa P-P Plot titik-titik yang mendekati dan menyebar di sekitar garis diagonal yang ada. Dengan demikian, dapat disimpulkan bahwa model regresi menunjukkan pola distribusi normal.

Uji multikoliniaritas; pengujian multikolinearitas dilakukan untuk mengetahui apakah dalam model ditemukan adanya korelasi antarvariabel bebas. Pada model regresi yang baik seharusnya tidak terjadi korelasi di antara berbagai variabel independen. Pendeteksian dilakukan dengan melihat VIF, yaitu jika nilai VIF lebih kecil dari 10, model bebas dari multikoliniaritas. Tabel 2 berikut adalah hasil hitung VIF.

Tabel 2 Hasil Perhitungan VIF

\begin{tabular}{lcc}
\hline \multirow{2}{*}{ Model/variable } & \multicolumn{2}{c}{ Collinearity Statistics } \\
\cline { 2 - 3 } & Tolerance & VIF \\
\hline (Constant) & & \\
Current Ratio (X1) &, 351 & 2,849 \\
Asset Turn Over (X2) &, 185 & 5,407 \\
Return On Asset (X3) &, 237 & 4,214 \\
Debt to Asset Ratio (X4) &, 342 & 2,925 \\
\hline
\end{tabular}

(Sumber: diolah sendiri)

Berdasarkan hasil analisis, nilai tolerance untuk variabel X1, X2, X3, dan X4, berturut-turut adalah 0,351, 0,185, 0,237, 0,242 dengan nilai tukar (VIF) berturut-turut adalah 2,849, 5,407, 4,214, 2,925. Jadi nilai keempat variabel independen berada di atas 0,1 dan semua nilai VIF di bawah 10. Maka dapat disimpulkan bahwa data tersebut tidak mengandung multikolinearitas.

\section{Pengujian Hipotesis}

Tujuan dari penelitian ini adalah untuk mengetahui apakah terdapat pengaruh kinerja keuangan perusahaan pembiayaan yang diwakili Current Ratio (X1), Assets Turn Over (X2), Return On Asset (X3), dan Debt Ratio (X4) terhadap Harga Pasar Saham (Y). Untuk itu, pada uji hipotesis dilakukan pengujian terhadap variabel-variabel dependen dan independen secara parsial dengan menggunakan uji t, dan simultan dengan uji F. 


\section{Pengujian Secara Parsial dengan Uji t}

Berikut adalah hasil olah SPSS tetang apakah ada atau tidak adanya pengaruh variabelvariabel independen secara individual terhadap variabel dependen yang diperoleh dalam penelitian.

Tabel 3 Hasil Uji t

\begin{tabular}{lccc}
\hline \multicolumn{1}{c}{ Variabel Independen } & Beta & Significant & Kesimpulan \\
\hline Current Ratio (X1) &,- 209 &, 738 & Berpengaruh \\
Assets Turn Over (X2) &,- 778 &, 121 & Berpengaruh \\
Return In Invesment (X3) &,- 235 &, 703 & Berpengaruh \\
Debt Ratio (X4) &, 546 &, 341 & Berpengaruh \\
\hline a. Dependent Variable (Y): Harga Saham & &
\end{tabular}

(Sumber: diolah sendiri)

Berikut penjelaskan terhadap pengujian hipotesis masing-masing variabel.

Current Ratio (X1) terhadap Harga Pasar Saham (Y); koefisien X1 terhadap Y memiliki hasil signifikansi sebesar 0,738 yang lebih besar dari 0,05. Artinya, Hipotesis 1 (Ho1) ditolak dan Ha1 diterima. Sehingga dapat disimpulkan bahwa ada pengaruh positif dan signifikan antara Current Ratio (X1) terhadap Harga Pasar Saham (Y).

Asset Turn Over (X2) terhadap Harga Pasar Saham (Y); berdasarkan hasil perhitungan koefisien X2 terhadap Y didapat hasil signifikansi sebesar 0,121 yang lebih besar dari 0,05. Artinya, Hipotesis 2 (Ho2) ditolak dan Ha2 diterima. Sehingga dapat disimpulkan bahwa ada pengaruh positif dan signifikan antara Asset Turn Over (X2) terhadap Harga Pasar Saham (Y).

Return On Asset (X3) terhadap Harga Pasar Saham (Y); koefisien X3 terhadap Y memiliki hasil signifikansi sebesar 0,703 yang lebih besar dari 0,05. Artinya, Hipotesis 3 (Ho3) ditolak dan Ha3 diterima. Sehingga dapat disimpulkan bahwa ada pengaruh positif dan signifikan antara Return On Asset (X3) terhadap Harga Pasar Saham (Y).

Return On Asset (X2) terhadap Harga Pasar Saham (Y); hasil perhitungan koefisien X4 terhadap Y didapat hasil signifikansi sebesar 0,341 yang lebih besar dari 0,05. Artinya, Hipotesis 4 (Ho4) ditolak dan Ha4 diterima. Sehingga dapat disimpulkan bahwa ada pengaruh positif dan signifikan antara Debt Ratio (X2) terhadap Harga Pasar Saham (Y).

\section{Pengujian Secara Simultan dengan Uji F}

Uji F digunakan untuk mengetahui bahwa ada atau tidak adanya pengaruh secara bersamasama atau simultan antara beberapa variabel independen (X1, X2, X3, dan X4) terhadap variabel dependen (Y). Hasil dari uji hipotesis yang dilakukan adalah seperti yang dimuat pada tabel berikut.

Tabel 4 Uji Statistik F

\begin{tabular}{llccccc}
\multicolumn{8}{c}{ ANOVA } \\
\hline \multicolumn{1}{c}{ Model } & Sum Squares & Df & Mean Square & F & Sig. \\
\hline Regression & 838376,64 & 1 & 838376,064 & & \\
Residual & 1973793,628 & 3 & 1973793,628 & & \\
Total & 2812169,692 & 4 & 2182169,692 & 1,274 & 0,41 \\
\hline
\end{tabular}

(Sumber: diolah sendiri) 
Berdasarkan hasil perhitungan uji F, diperoleh nilai F sebesar 1,274 dengan nilai signifikansi 0,41. Hal ini menunjukkan nilai siginifikansi probabilitas lebih kebesar dari 0,05. Maka dapat disimpulkan bahwa Current Ratio (X1), Asset Turn Over (X2), Return On Asset (X3), dan Debt Ratio (X4) secara simultan berpengaruh terhadap Harga Pasar Saham (Y).

\section{SIMPULAN}

Berdasarkan hasil penelitian dan analisis yang dilakukan, dapat disimpulkan bahwa dari hasil uji t yang menguji pengaruh beberapa variabel independen terhadap variabel dependen menyatakan bahwa semua nilai signifikansi (t hitung) berada di atas 0,05 . Hasil pengujian tersebut adalah sebagai berikut. Pertama, ada pengaruh yang signifikan antara variabel Current Ratio terhadap Haraga Pasar Saham. Kedua, ada pengaruh signifikan antara Asset Turn Over dengan Harga Pasar Saham. Ketiga, ada pengaruh signifikan antara Return On Asset terhadap Harga Pasar Saham. Keempat, ada pengaruh signifikan antara Debt Ratio terhadap Harga Pasar Saham. Demikian juga pengujian berganda yang dilakukan, diketahui bahwa ada pengaruh positif dan signifikan antara semua variabel independen X1, X2, X3, dan X4 terhadap Harga Pasar Saham karena nilai signifikansi (F hitung) berada di atas 0,05. Jadi, semua indikator kinerja keuangan yang diteliti pada 6 perusahaan pembiayaan terbuka memengaruhi Harga Pasar Saham. Hal ini sesuai dengan penelitian yang terdahulu dilakukan Anwar (2009).

Hasil penelitian ini diharapkan dapat digunakan para investor dan calon investor dalam melakukan analisis atas rencana investasi yang dilakukan. Kemudian, kepada peneliti selanjutnya diharapkan dapat melakukan penelitian lanjutan yang lebih luas dengan memperbanyak variabel penelitian. Hal tersebut dilakukan untuk mengetahui lebih banyak faktor kinerja keuangan yang dapat/tidak dapat memengaruhi perubahan harga pasar saham perusahaan pembiayaan terbuka.

\section{DAFTAR PUSTAKA}

Anwar, S. (2009). Pengaruh Faktor Fundamental dan Risiko Sistematis terhadap Harga Saham Perusahaan Sektor Pembiayaan di BEI, tahun 2007-2008. Universitas Gunadarma, Jakarta.

http://www.gunadarma.ac.id/library/articles/graduate/economy/2009/Artikel_11205179.pdf

Bursa Efek Indonesia. (2013). Laporan Keuangan dan Tahunan. www.bapepam.go.id

Leenden, L. (2003). Leasing Untuk Usaha Kecil dan Mikro. Organisasi Perburuh Internasional.

Pratisto, A. (2009). Statistik Menjadi Mudah dengan SPSS 17. Jakarta: Elex Media Komputindo.

Priyatno, D. (2011). Belajar Cepat Olah Data Statistik dengan SPSS. Yogyakarta: Andi.

Sugiyono. (2005). Metodologi Penelitian Bisnis. Bandung: Alfabeta.

Tandelilin, E. (2011). Portfolio dan Investasi. Yogyakarta: Kanisius. 


\section{LAMPIRAN}

Tabel 5 Hasil Perhitungan Current Ratio (X1)

\begin{tabular}{lrrrrr} 
Nama Perusahaan & $\mathbf{2 0 0 8}$ & $\mathbf{2 0 0 9}$ & $\mathbf{2 0 1 0}$ & $\mathbf{2 0 1 1}$ & $\mathbf{2 0 1 2}$ \\
\hline CFIN & 3.97 & 2.78 & 2.21 & 2.7 & 1.45 \\
WOMF & 2.35 & 2.22 & 1.48 & 1.82 & 6.71 \\
ADMF & 0.00 & 7.15 & 10.9 & 4.5 & 1,56 \\
BPFI & 1.61 & 2.8 & 2.16 & 2.06 & 1.66 \\
VRNA & 1.29 & 1.34 & 1.27 & 2.61 & 2.37 \\
DEFI & 25.9 & 101.9 & 109.1 & 131.5 & 25.9 \\
\hline \multicolumn{1}{c}{ Rata-rata } & $\mathbf{2 3 . 4 3}$ & $\mathbf{3 5 . 8 2}$ & $\mathbf{3 6 . 3 2}$ & $\mathbf{4 1 . 5 0}$ & $\mathbf{6 . 6 0}$ \\
\hline
\end{tabular}

(Sumber: diolah sendiri)

Tabel 6 Hasil perhitungan Asset Turn Over (X2)

\begin{tabular}{lccccc} 
Nama Perusahaan & $\mathbf{2 0 0 8}$ & $\mathbf{2 0 0 9}$ & $\mathbf{2 0 1 0}$ & $\mathbf{2 0 1 1}$ & $\mathbf{2 0 1 2}$ \\
\hline CFIN & 0.20 & 0.19 & 0.15 & 0.16 & 0.14 \\
WOMF & 0.00 & 0.54 & 0.40 & 0.42 & 0.48 \\
ADMF & 0.94 & 0.91 & 0.51 & 0.31 & 0.27 \\
BPFI & 0.25 & 0.38 & 0.24 & 0.24 & 0.14 \\
VRNA & 0.24 & 0.24 & 0.20 & 0.16 & 030 \\
DEFI & 0.07 & 0.03 & 0.07 & 0.07 & 0.05 \\
\hline \multicolumn{1}{c}{ Rata-rata } & $\mathbf{0 . 2 8}$ & $\mathbf{0 . 3 8}$ & $\mathbf{0 . 2 6}$ & $\mathbf{0 . 2 7}$ & $\mathbf{0 . 2 4}$ \\
\hline
\end{tabular}

(Sumber: diolah sendiri)

Tabel 7 Hasil Perhitungan Return On Asset (X3)

\begin{tabular}{lrrrrr} 
Nama Perusahaan & $\mathbf{2 0 0 8}$ & $\mathbf{2 0 0 9}$ & $\mathbf{2 0 1 0}$ & $\mathbf{2 0 1 1}$ & $\mathbf{2 0 1 2}$ \\
\hline CFIN & 0.08 & 0.08 & 0.07 & 0.06 & 0.07 \\
WOMF & 0.00 & 0.02 & 0.04 & 0.01 & 0.02 \\
ADMF & 0.07 & 0.28 & 0.19 & 0.09 & 0.06 \\
BPFI & 0.06 & 0.13 & 0.09 & 0.08 & 0.04 \\
VRNA & 0.03 & 0.03 & 0.03 & 0.02 & 0.02 \\
DEFI & -1.3 & -.0 .05 & 0.04 & 0.04 & 0.02 \\
\hline \multicolumn{1}{c}{ Rata-rata } & $\mathbf{0 . 0 3}$ & $\mathbf{0 . 0 9}$ & $\mathbf{0 . 1 1}$ & $\mathbf{0 . 0 5}$ & $\mathbf{0 . 0 4}$ \\
\hline
\end{tabular}

(Sumber: diolah sendiri)

Tabel 8 Hasil Return on Asset (X4)

\begin{tabular}{lrrrrr} 
Nama Perusahaan & $\mathbf{2 0 0 8}$ & $\mathbf{2 0 0 9}$ & $\mathbf{2 0 1 0}$ & $\mathbf{2 0 1 1}$ & $\mathbf{2 0 1 2}$ \\
\hline CFIN & 0.27 & 0.26 & 0.45 & 0.54 & 0.32 \\
WOMF & 0.27 & 0.92 & 0.87 & 0.89 & 0.87 \\
ADMF & 0.48 & 0.39 & 0.50 & 0.74 & 0.48 \\
BPFI & 0.61 & 0.34 & 0.50 & 0.55 & 0.48 \\
VRNA & 0.80 & 0.79 & 0.83 & 0.88 & 0.40 \\
DEFI & 0.02 & 0.01 & 0.01 & 0.009 & 0.01 \\
\hline \multicolumn{1}{c}{ Rata-rata } & $\mathbf{0 . 4}$ & $\mathbf{0 . 4 5}$ & $\mathbf{0 . 5 3}$ & $\mathbf{0 . 6 0}$ & $\mathbf{0 . 4 4}$ \\
\hline
\end{tabular}

(Sumber: diolah sendiri) 
Tabel 9 Hasil Perhitungan Rata-rata Harga Pasar Saham (Y)

\begin{tabular}{|c|c|c|c|c|c|}
\hline Nama Perusahaan & 2008 & 2009 & 2010 & 2011 & 2012 \\
\hline CFIN & 1303.2 & 647.5 & 663.3 & 564.3 & 778.6 \\
\hline WOMF & 189.6 & 120.5 & 398 & 393 & 189 \\
\hline ADMF & 1999.6 & 4016 & 2692 & 11817 & 11279 \\
\hline BPFI & 572.9 & 679.1 & 1266 & 2595 & 2221 \\
\hline VRNA & 66.33 & 61.91 & 93.41 & 134.4 & 119.6 \\
\hline DEFI & 698.3 & 524.2 & 625 & 1032 & 602.5 \\
\hline Rata-rata & 805 & 991.6 & 2122.9 & 2755.9 & 2192.3 \\
\hline
\end{tabular}

(Sumber: diolah sendiri) 